\title{
Clearance of a dermal Huffmanela sp. in a sandbar shark (Carcharhinus plumbeus) using levamisole
}

\author{
Robert A. MacLean ${ }^{1,2,6}$, Michael H. Fatzinger ${ }^{3}$, Kevin D. Woolard ${ }^{4}$, \\ Craig A. Harms ${ }^{1,5, *}$ \\ ${ }^{1}$ Environmental Medicine Consortium, College of Veterinary Medicine, North Carolina State University, \\ 4700 Hillsborough Street, Raleigh, North Carolina 27606, USA \\ ${ }^{2}$ The North Carolina Zoological Park, 4401 Zoo Parkway, Asheboro, North Carolina 27203, USA \\ ${ }^{3}$ North Carolina Aquariums at Fort Fisher, 900 Loggerhead Road, Kure Beach, North Carolina 28449, USA \\ ${ }^{4}$ Department of Population Health and Pathobiology, College of Veterinary Medicine, North Carolina State University, \\ 4700 Hillsborough Street, Raleigh, North Carolina 27606, USA \\ ${ }^{5}$ North Carolina State University Center for Marine Science and Technology, 303 College Circle, Morehead City, \\ North Carolina 28557, USA \\ ${ }^{6}$ Present address: The Audubon Institute, 6500 Magazine Street, New Orleans, Louisiana 70118, USA
}

\begin{abstract}
A wild-caught captive sandbar shark Carcharhinus plumbeus developed a contiguous network of darkly pigmented linear tracks that progressed from the snout to the ventral cervical region. Microscopic examination of a skin scraping revealed nematode eggs of the genus Huffmanela, a group of histozoic nematodes that is known to parasitize requiem sharks and marine and freshwater teleosts. The fresh eggs were darkly pigmented with bipolar plugs, contained a larva, and measured 73.3 to 86.4 by 39.0 to $47.4 \mu \mathrm{m}(\mathrm{n}=10)$. Formalin-fixed and paraffin-embedded eggs were significantly smaller (Wilcoxon rank sums test, $\mathrm{p}<0.005$ ), measuring 70.5 to 78.9 by 33.6 to $41.3 \mu \mathrm{m}$ $(\mathrm{n}=13)$. These measurements do not correlate with previously reported species of Huffmanela. Serial treatment with levamisole $\left(10 \mathrm{mg} \mathrm{kg}^{-1}\right.$, intramuscular [i.m.]) cleared the egg tracks within $21 \mathrm{~d}$, with no recurrence or apparent complications.
\end{abstract}

KEY WORDS: Parasitic nematode · Huffmanela · Carcharhinus plumbeus · Elasmobranchii · Levamisole

We describe a case of histozoic nematode parasitism by a species of Huffmanela on an exhibited sandbar shark Carcharhinus plumbeus that cleared after treatment with levamisole. In January 2005, a $6.3 \mathrm{~kg}$ female sandbar shark at the North Carolina Aquarium at Fort Fisher was noted to have developed gray swirls on its white ventral nasal and mandibular regions. This individual was collected from the Cape Fear River in coastal North Carolina, USA, on 12 August 2004, and was placed in a 640001 quarantine tank with conspecifics and other elasmobranchs (bonnethead sharks Sphyrna tiburo, southern stingrays Dasyatis americana, and spinner sharks Carcharhinus brevipinna) after a 5 min freshwater bath. On 30 November 2004 this shark was placed into a 8900001 mixed-species exhibit containing 8 conspecifics, bonnethead sharks, southern stingrays, and multiple species of bony fish. The shark was fed a variety of supplemented (Vita-Zu Sharks/Rays II, Mazuri) mackerel and squid twice weekly, and had a good appetite through 3 February 2005.

The shark was examined on 4 February 2005, retrieved from the exhibit and manually restrained in dorsal recumbency within a sling. A reticular network of contiguous, gray, swirling linear tracks approx. $1 \mathrm{~mm}$ wide formed a band 3 to $4 \mathrm{~cm}$ wide in the white 
skin. These tracks wended their way from the right ventral snout to the left side of the mouth, reducing to a single track past the dorsal aspect of the left commissure, then once again formed a wide band that progressed caudomedially to terminate in the ventral cervical region, losing definition in the last $2 \mathrm{~cm}$ (Fig. 1).

Blood was collected into sodium heparin from the caudal hemal arch using a 22 gauge $38 \mathrm{~mm}$ needle and a $6 \mathrm{ml}$ syringe, then placed into a vial as part of the initial health evaluation. A differential blood count was performed manually, and plasma chemistry analyses were performed by automated bichromatic spectrophotometry (albumin, calcium, phosphorus, bicarbonate and glucose concentrations, and aspartate aminotransferase and lactate dehydrogenase activities) and ion-selective electrode (sodium, potassium and chloride concentrations) on a Roche/Hitachi 912 Clinical Chemistry System (Roche Molecular Systems) (Table 1) (Stoskopf 1993a, 2000). When compared with previously reported values obtained from elasmobranchs (excluding compromised individuals), potassium concentrations in this specimen appeared to be lower and lactate dehydrogenase activity appeared to be higher; however, the clinical significance of these values is uncertain (Stoskopf 2000, Harms et al. 2002). A skin scrape of the pattern was collected approximately $2 \mathrm{~cm}$ caudal to the snout using a Number 10

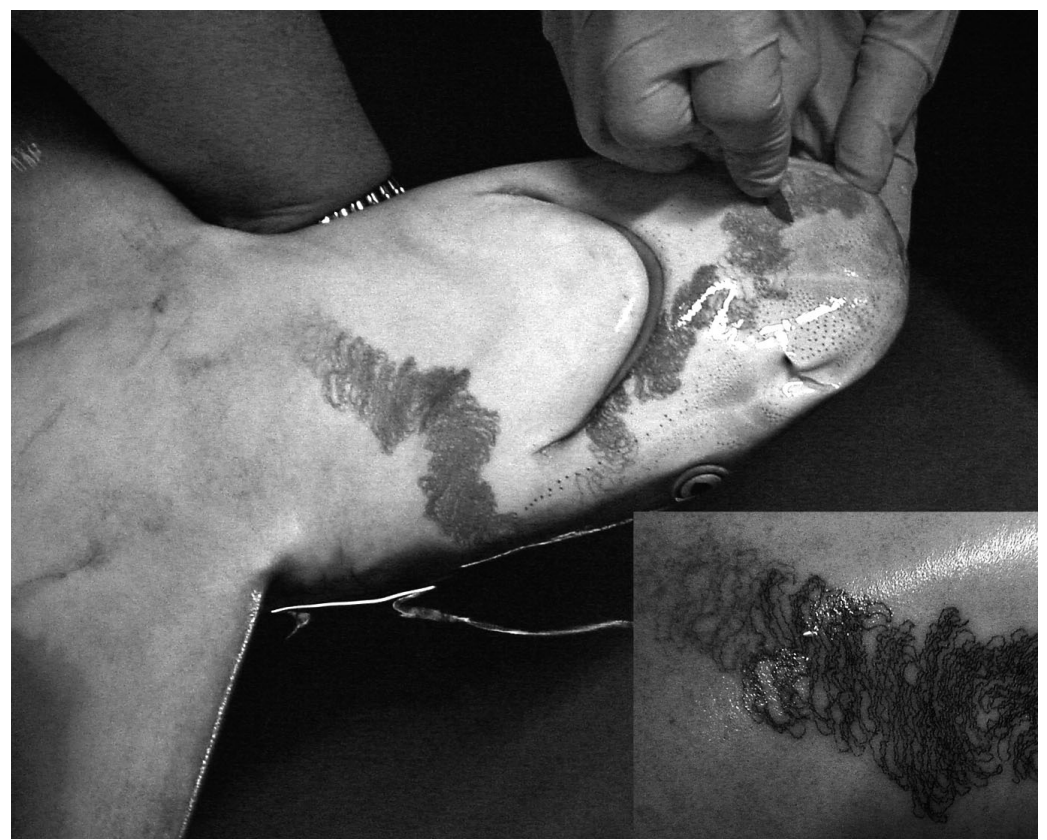

Fig. 1. Carcharhinus plumbeus. Scraping of pigmented linear tracks noted on skin of an exhibited shark, caused by eggs deposited by a Huffmanela sp. nematode. Inset: enlarged view of the caudal portion of egg tracks scalpel blade and placed with a drop of exhibit water onto a glass slide with a coverslip sealed at the edges with ophthalmic ointment (to prevent desiccation) for examination. The shark was then moved into an offexhibit 260001 holding tank.

Examination of the slide under a microscope revealed numerous darkly pigmented, trichuroid ova with bipolar plugs and thick, dark brown, apparently rugose shells that were embryonated with a motionless coiled larva (Fig. 2). The shell was covered with a thin transparent vitelline envelope and had a thickened chitinous layer at both ends that surrounded the slightly protruding polar plugs, forming a collar. Ten fresh eggs were measured in $\mu \mathrm{m}$ using a calibrated microscope (Eclipse E600, Nikon) with a 40× objective and digital imaging software (Image-Pro Plus v. 4.5, Media Cybernetics). Measurement data are presented in Table 2. The median embryo width was 8.6 (10th and 90th percentiles: 6.7 and 9.4 respectively; range: 6.2 to 9.4). Ova resembled those of the genus Huffmanela, which are nematode parasites of marine and freshwater fish.

The shark was re-examined $12 \mathrm{~d}$ after the initial sampling, and it was noted that the rostral area of gray tracks from which the skin scrape had been taken had faded considerably. However, the ventral cervical band of tracks had become more defined and darkened at its terminus. No adult nematodes were visible under head loupe magnification. 


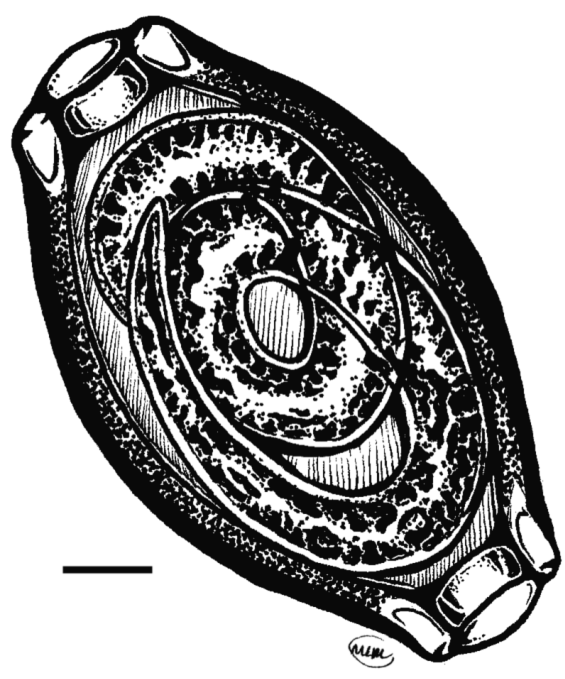

Fig. 2. Huffmanela sp.. Artistic rendering of a photomicrograph of an embryonated egg recovered by a skin scrape from an exhibited shark (Carcharhinus plumbeus). Scale bar $=10 \mu \mathrm{m}$

Two full-thickness $6 \mathrm{~mm}$ skin punch biopsies were taken (Keyes dermal punch, Miltex), using a local block of $2 \%$ lidocaine (Lidoject $\mathrm{Rx}$, Vetus Animal Health; $0.3 \mathrm{ml}$ intramuscular [i.m.] and intradermal) at each site without additional skin preparation. The biopsies included the edge of egg tracks: one from the left ventral jaw line and one from the right ventral cervical (terminus) region. The skin defects were closed with a single suture of 2-0 polydioxanone (PDS II, Ethicon, Novartis Animal Health US) in a cruciate pattern, and a topical antibiotic ointment was applied (neomycin, polymyxin and bacitracin, Neosporin, Warner-Lambert Consumer Healthcare). The biopsies were placed immediately into $10 \%$ neutral buffered formalin and were later processed for histological examination using a standard paraffin technique, sec- tioned at $5 \mu \mathrm{m}$, and stained with hematoxylin and eosin. The ova described above were seen on histological section; however, no adults or migration tracks were found through serial sectioning. No targeted inflammatory response to ova was noted, indicating that this nematode is likely host-adapted. Each measurement was also taken from at least 13 eggs ( $\mathrm{n}>13$ ) in the histological sections, where both polar plugs were visible in their entirety (Table 2). The entire wall thickness and pigmented portion were both measured at the center of the ova. Measurements recorded from histological sections were significantly smaller (Wilcoxon rank sums test, $\mathrm{p}<0.005$ ) than those taken from the fresh mounts.

Even though lesions were minimal, this shark was an exhibit animal and thus treatment was attempted to restore the animal to display quality. Levamisole (Levasole, Schering Plough Animal Health; $10 \mathrm{mg} \mathrm{kg}^{-1}$, $64 \mathrm{mg}$ i.m.) was administered and repeated after 14 and $28 \mathrm{~d}$. Vitamin B complex (Phoenix Scientific; $6 \mathrm{mg}$ $\mathrm{kg}^{-1}$ thiamine, $0.4 \mathrm{ml}$ i.m.) was also given as an appetite stimulant because the animal had been inappetant since being moved off exhibit. The animal was force-fed squid $5 \mathrm{~d}$ later and was eating on its own within 1 wk. Upon re-examination $26 \mathrm{~d}$ after initial exam and $14 \mathrm{~d}$ after treatment with levamisole, there was no further progression of parasitism and the egg tracks were fading. At the biopsy sites, there was a near complete absence of egg tracks within a 0.5 to $2 \mathrm{~cm}$ radius of the incisions. The sutures were removed and the dose of levamisole repeated. The animal was noted to have a non-healing snout abrasion as well as a cloudy left eye, presumed to be tank trauma, and a course of amikacin (Amiglyde-V, Fort Dodge Laboratories; $3.2 \mathrm{mg} \mathrm{kg}^{-1}, 20 \mathrm{mg}$ i.m., every $72 \mathrm{~h}$ for 8 doses) was prescribed. Another skin scrape was performed as before, and multiple eggs were again present; however, these eggs were not as dark as those previously

Table 2. Huffmanela sp. Measurements $(\mu \mathrm{m})$ of ova from an exhibited shark (Carcharhinus plumbeus) taken from photomicrographs of freshly mounted $(F, n=10)$ and histologically sectioned $(H, n=13)$ ova, including length $(L)$, width $(W)$, depth $(D)$, entire wall thickness (Wall T), and pigmented wall thickness (P Wall T). Height (Ht) of the protruding part of the plug was measured only for fresh eggs. \%: percentile; na: not applicable

\begin{tabular}{|c|c|c|c|c|c|c|c|c|c|}
\hline Ova & Statistic & $\mathrm{L}$ & Center W & Collar W & Plug D & Plug W & Plug Ht & Wall T & P Wall T \\
\hline \multirow[t]{4}{*}{ F } & Range & $73.3-86.4$ & $39.0-47.4$ & $19.6-22.3$ & $6.7-10.4$ & $9.8-12.3$ & $0.6-4.1$ & na & na \\
\hline & Median & 80.2 & 40.6 & 21.2 & 7.9 & 11.2 & 2.5 & na & na \\
\hline & 10 th \% & 74.6 & 39.4 & 19.8 & 7.1 & 10.1 & 1.7 & na & na \\
\hline & 90 th \% & 85.9 & 46.7 & 22.3 & 9.7 & 12.2 & 3.8 & na & na \\
\hline \multirow[t]{4}{*}{$\mathbf{H}$} & Range & $70.5-78.9$ & $33.6-41.3$ & $16.0-18.6$ & $9.9-16.0$ & $3.8-6.8$ & & $3.3-6.6$ & $2.2-4.6$ \\
\hline & Median & 74.6 & 37.5 & 16.9 & 13.1 & 5.1 & & 5.4 & 3.5 \\
\hline & 10 th \% & 72.6 & 34.1 & 16.4 & 12.0 & 4.4 & & 4.0 & 3.1 \\
\hline & 90th \% & 76.6 & 39.9 & 18.1 & 15.3 & 5.7 & & 5.8 & 4.2 \\
\hline Total & Range & $70.5-86.4$ & $33.6-47.4$ & $16.0-22.3$ & na & na & na & na & na \\
\hline
\end{tabular}


examined and appeared to have a thin shell. Many eggs were broken and empty, others were cracked and contained motionless larvae either within or partially exteriorized, and the remaining eggs were intact with larvae that were more clearly visible than in previous specimens examined 26 d before. On Day 40 after initial examination (28 d after the first dose of levamisole) the egg tracks had continued to fade, and the third dose of levamisole was administered. On Day 53 (41 d after the first dose of levamisole) the vast majority of the egg tracks and the left eye lesion had completely resolved.

The rapid loss of egg tracks from the areas of the initial skin scrape and biopsy sites is noteworthy. It is unlikely that the eggs were mechanically removed from the skin because the tracks were still present after the scraping and biopsies. It is more likely that, while the nematode and its eggs did not elicit an appreciable inflammatory response by the host, our manipulations may have initiated a local response robust enough to clear the parasite. Treatment with levamisole was elected because of its wide spectrum of activity against nematodes and its safe application to elasmobranchs (Stoskopf 1993b). Interestingly, levamisole is also known to elicit immunostimulatory effects in many species, including marine fishes (Mulero et al. 1998). A subsequent case involving another specimen of Carcharhinus plumbeus was treated successfully at this facility with the same protocol. Moreover, another institution reported similar skin lesions on 3 sandbar sharks that resolved with 2 oral doses of $10 \mathrm{mg} \mathrm{kg}^{-1}$ levamisole spaced $14 \mathrm{~d}$ apart (M. Stamper pers. comm.). Although ivermectin has been listed as a possible quarantine treatment for sharks (Davis 2004), anecdotal reports of toxicity in chondrichthyans (Benz \& Bullard 2004) and documented toxicity at therapeutic doses in some teleost fish (Athanassopoulou et al. 2002) led us to avoid its use.

Huffmanela spp. are histozoic nematodes that deposit their ova in the skin, muscle, swimbladder, gill arch, bone, and/or viscera of marine and at least one freshwater fish. Eleven described species of Huffmanela and at least 3 innominate spp. have been described from eggs alone, and adults have been described for an additional 2 species (Table 3) (Huffman \& Moravec 1988, Justine 2005, Moravec et al. 2005). The adults of $H$. huffmani are found in the swimbladder of freshwater centrarchid fish and only inhabit the upper San Marcos River of central Texas, USA (Cox et al. 2004). The adults of $H$. canadensis are found in the skin of rockfish (Sebastes spp.) off the coast of Vancouver Island, British Columbia, Canada (Moravec et al. 2005). Huffmanela spp. are small, filariform nematodes and the latter species, $H$. canadensis, measure between 3 and $8 \mathrm{~mm}$ in length, making them difficult to find on a routine examination of lesions (Huffman \& Moravec 1988, Moravec et al. 2005). In fact, adults of $H$. canadensis were not observed during thorough inspection of the egg mass using a dissecting microscope; rather, they were discovered retrospectively through examination of serial histological sections of the skin lesion (Moravec et al. 2005). Although serial sectioning was performed in the present study, only 2 skin biopsies were available rather than whole lesions, and adults may simply have been missed during examination. However, it is possible that adults were not present, as the eggs and their tracks were darkly pigmented and embryonated; eggs of Huffmanela spp. are thought to be thin-shelled, light colored, and unembryonated at oviposition, with progressive darkening during maturation (Huffman \& Moravec 1988, Moravec et al. 1998).

Huffmanela carcharhini was described from its ova alone, and has been reported to cause linear ventral skin lesions in requiem sharks including Carcharhinus plumbeus as a result of bipolar egg deposition around the bases of the placoid scales (Moravec 1987, Caira \& Healy 2004). The sharks of these previous studies were also caught off the coast of the southern USA, and their skin lesions were identical in gross appearance to those reported in this study. The ova did not have protruding polar plugs and were reported to measure 90 to 105 by 42 to $54 \mu \mathrm{m}$, which is on average longer and wider than reported here (Moravec 1987, Justine 2004). H. canadensis also deposits dark linear tracks of eggs in the skin of rockfish that are analogous to those seen in this case (Moravec et al. 2005). Two other Huffmanela species known to cause skin lesions include $H$. paronai, described from ova observed in the swordfish Xiphias gladius, and H. lata, described from another requiem shark (the grey reef shark Carcharhinus amblyrhynchos) (Moravec \& Garibaldi 2000, Justine 2005). However, the eggs of these 2 species are deposited in discrete spots, not linear tracks. Moreover, the eggs of $H$. paronai are both shorter and narrower, and those of $H$. lata wider, than those observed in the present case. We used the key provided by Moravec (2001) to identify eggs of Huffmanela spp., and considered the ova observed in this study to most closely match $H$. shikokuensis, but distinct discrepancies in the appearance, distribution, and host of the nematode ova were apparent (Moravec et al. 1998). However, the Moravec (2001) key is outdated, and Huffmanela spp. are incompletely characterized and probably widely distributed in marine fishes (Moravec et al. 1998).

In light of the above discussion, it is likely that ova observed in the present case are from an as yet undescribed species of Huffmanela, but insufficient material was preserved to facilitate such a description. How- 
Table 3. Comprehensive list of Huffmanela spp. described as of 2006. External features of ova, known host species, and affected tissues included

\begin{tabular}{|c|c|c|c|c|c|c|}
\hline Species & $\begin{array}{l}\text { Length } \\
(\mu \mathrm{m})\end{array}$ & $\begin{array}{l}\text { Width } \\
(\mu \mathrm{m})\end{array}$ & Feature & Host & Tissue & Source \\
\hline H. carcharhini & $90-105$ & $42-54$ & Aspinose & Carcharhinidae & Skin, gill arch & Moravec (1987) \\
\hline H. banningi & $80-100$ & $40-50$ & Spinose & $\begin{array}{l}\text { Sole } \\
\text { Cynoglossus spp. }\end{array}$ & Muscle & Moravec (1987) \\
\hline H. huffmani & $54-60$ & $30-39$ & Spinose & Centrarchidae & Swimbladder & $\begin{array}{l}\text { Huffman \& } \\
\text { Moravec (1988) }\end{array}$ \\
\hline H. schouteni & $69-75$ & $27-30$ & Aspinose & Exocoetidae & Coelomic serosa & $\begin{array}{l}\text { Moravec \& } \\
\text { Campbell (1991) }\end{array}$ \\
\hline H. japonica & $58-69$ & $26-30$ & Aspinose & Mullidae & Muscle & Moravec et al. (1998) \\
\hline H. shikokuensis & $78-90$ & $36-45$ & Aspinose & Monacanthidae & Muscle & Moravec et al. (1998) \\
\hline H. paronai & $48-51$ & $21-24$ & Aspinose & $\begin{array}{l}\text { Swordfish } \\
\text { Xiphias gladius }\end{array}$ & Skin & $\begin{array}{l}\text { Moravec \& } \\
\text { Garibaldi (2000) }\end{array}$ \\
\hline H. mexicana & $63-69$ & $30-33$ & Aspinose & Tetraodontiform fish & Swimbladder & $\begin{array}{l}\text { Moravec \& } \\
\text { Fajer-Avila (2000) }\end{array}$ \\
\hline H. ossicola & $72-80$ & $32-40$ & Filamentous & $\begin{array}{l}\text { Blackfin hogfish } \\
\text { Bodianus loxozonus }\end{array}$ & Bone & Justine (2004) \\
\hline H. branchialis & $45-52$ & $23-30$ & Aspinose & $\begin{array}{l}\text { Bream } \\
\text { Nemipterus furcosus }\end{array}$ & Gill mucosa & Justine (2004) \\
\hline H. filamentosa & $48-53$ & $25-30$ & Filaments & $\begin{array}{l}\text { Bream } \\
\text { Gymnocranius grandoculis }\end{array}$ & Gill mucosa & Justine (2004) \\
\hline H. canadensis & $50-55$ & $21-27$ & Ridges & $\begin{array}{l}\text { Rockfish } \\
\text { Sebastes spp. }\end{array}$ & Skin & $\begin{array}{l}\text { Moravec et al. } \\
(2005)\end{array}$ \\
\hline H. lata & $77-88$ & $52-63$ & Spinose & $\begin{array}{l}\text { Grey reef shark } \\
\text { Carcharhinus amblyrhynchos }\end{array}$ & Skin & Justine (2005) \\
\hline Huffmanela sp. & 114 & 60 & Not described & $\begin{array}{l}\text { Unknown fish, } \\
\text { New Zealand }\end{array}$ & Muscle & $\begin{array}{l}\text { Grabda \& } \\
\text { Slosarczyk (1981) }\end{array}$ \\
\hline Huffmanela sp. & $67-79$ & $34-43$ & Punctate & $\begin{array}{l}\text { Unknown, obtained } \\
\text { from human stool, } \\
\text { Spain }\end{array}$ & Unknown & Gállego et al. (1993) \\
\hline Huffmanela sp. & $39-47$ & $22-27$ & Aspinose & $\begin{array}{l}\text { Bream } \\
\text { Pentapodus sp. }\end{array}$ & Mouth mucosa & Justine (2004) \\
\hline Huffmanela sp. & $73-86$ & $39-47$ & Aspinose & $\begin{array}{l}\text { Sandbar shark } \\
\text { C. plumbeus }\end{array}$ & Skin & Present study \\
\hline
\end{tabular}

ever, intraspecific morphological differences in ova have been reported within the same species of nematode, including $H$. ossicola, perhaps resulting from differences in the nutritional status of the egg-laying female (Justine 2004). Other factors affecting morphology may include fixation artifacts: in this study, eggs that were measured fresh in tank water were larger than those measured after fixation for histopathology. Many (but not all) reports measure eggs after storage in ethanol and clearance with glycerine. Although our measurements differ from those reported previously, it is possible that the ova observed here could belong to $H$. carcharini when similarities in host, ova morphology, and pattern of egg deposition are accounted for.

Studies of Huffmanela huffmani suggest that an intermediate host is required, which may limit the geographical distribution of species within this genus (Cox et al. 2004). It remains unclear when egg deposition commenced in the shark examined in the present case. No lesions were reported during the 3.5 mo quarantine; however, they did appear within weeks of being placed on exhibit. Several possibilities exist: (1) the adult nematode was present on the shark at capture and delayed in egg deposition, (2) immature eggs had been deposited but had not matured or darkened sufficiently to be visible, (3) an infected intermediate host for this nematode was present in the exhibit tank and released infective forms that then parasitized the shark. Treatment with levamisole appeared effective in eliminating the Huffmanela sp. from its definitive host - the sandbar shark — with no observed complications or reinfection in an aquarium setting.

Acknowledgements. We thank artist Michelle L. Mehalick for creating Fig. 2.

\section{LITERATURE CITED}

Athanassopoulou F, Hatzinikolaou S, Liberis N, Ragias V, Roth M (2002) Toxicity and pathological effects of orally and intraperitoneally administered ivermectin on sea bass Dicentrarchus labrax. Dis Aquat Org 52:69-76

Benz GW, Bullard SA (2004) Metazoan parasites and associates of chondrichthyans with emphasis on taxa harmful to captive hosts. In: Warmolts SMD, Thoney D, 
Heuter R (eds) Elasmobranch husbandry manual: captive care of sharks, rays, and their relatives. Special Publication of the Ohio Biological Survey, Columbus, $\mathrm{OH}, \mathrm{p}$ 325-416

Caira JN, Healy CJ (2004) Elasmobranchs as hosts of metazoan parasites. In: Carrier JC, Musick JA, Heithaus MR (eds) Biology of sharks and their relatives. CRC Press, Boca Raton, FL, p 523-551

Cox MK, Huffman DG, Moravec F (2004) Observations on the distribution and biology of Huffmanela huffmani (nematoda: Trichosomoididae). Folia Parasitol 51:50-54

Davis R (2004) Quarantine and prophylaxis for elasmobranchs. In: Warmolts SMD, Thoney D, Heuter R (eds) Elasmobranch husbandry manual: captive care of sharks, rays, and their relatives. Special Publication of the Ohio Biological Survey, Columbus, OH, p 143-150

Gállego J, Riera C, Portús M (1993) Huffmanela sp. eggs (Nematoda: Trichosomoididae), as a human spurious parasite in a child from Barcelona (Spain). Folia Parasitol 40: 208-210

Grabda J, Slóśarczyk W (1981) Parasites of marine fishes from New Zealand. Acta Ichthyol Piscat 11:85-103

Harms C, Ross T, Segars A (2002) Plasma biochemistry reference values of wild bonnethead sharks, Sphyrna tiburo. Vet Clin Pathol 31:111-115

Huffman DG, Moravec F (1988) First description of adult Huffmanela huffmani Moravec, 1987 (Nematoda: Trichosomoididae) from the swimbladder of centrarchid fishes of the upper San Marcos River, central Texas. Folia Parasitol 35:227-234

Justine J (2004) Three new species of Huffmanela Moravec, 1987 (Nematoda: Trichosomoididae) from the gills of marine fish off New Caledonia. Syst Parasitol 59:29-37

Justine J (2005) Huffmanela lata n. sp. (Nematoda: Trichosomoididae: Huffmanelinae) from the shark Carcharhinus amblyrhynchos (Elasmobranchii: Carcharhinidae) off New Caledonia. Syst Parasitol 61:181-184

Editorial responsibility: Robin Overstreet, Ocean Springs, Mississippi, USA
Moravec F (1987) Revision of capillariid nematodes (subfamily Capillariinae) parasitic in fishes. Studie ČSAV No. 3. Academia, Prague

Moravec F (2001) Systematic review of trichinelloid nematodes from poikilotherm hosts. In: Moravec F (ed) Trichinelloid nematodes parasitic in cold-blooded vertebrates. Academia, Prague, p 319-336

Moravec F, Campbell BG (1991) A new Huffmanela species, H. schouteni sp. n. (Nematoda: Trichosomoididae) from flying fishes in Curaçao. Folia Parasitol 38:29-32

Moravec F, Fajer-Avila E (2000) Huffmanela mexicana n. sp. (Nematoda: Trichosomoididae) from the marine fish Sphoeroides annnulatus in Mexico. J Parasitol 86:1229-1231

Moravec F, Garibaldi F (2000) Huffmanela paronai sp. n. (Nematoda: Trichosomoididae), a new parasite from the skin of swordfish Xiphias gladius in the Lugurian Sea (western Mediterranean). Folia Parasitol 47:309-313

Moravec F, Koudela B, Ogawa K, Nagasawa K (1998) Two new Huffmanela species, $H$. japonica n. sp. and $H$. shikokuensis n. sp. (Nematoda: Trichosomoididae), from marine fishes in Japan. J Parasitol 84:589-593

Moravec F, Conboy GA, Speare DJ (2005) A new trichosomoidid from the skin of Sebastes spp. (Pisces) from British Columbia, Canada. J Parasitol 91:411-414

Mulero V, Esteban MA, Munoz J, Messenger J (1998) Dietary intake of levamisole enhances the immune response and disease resistance of the marine teleost gilthead seabream (Sparus aurata L.). Fish Shellfish Immunol 8:49-62

Stoskopf MK (1993a) Clinical pathology. In: Stoskopf MK (ed) Fish medicine. W. B. Saunders, Philadelphia, PA, p 113-131

Stoskopf MK (1993b) Shark pharmacology and toxicology. In: Stoskopf MK (ed) Fish medicine. W. B. Saunders, Philadelphia, PA, p 809-816

Stoskopf MK (2000) Normal hematology of elasmobranchs. In: Feldman BF, Zinkl JG, Jain NC (eds) Schalm's veterinary hematology. Lippincott Williams \& Wilkins, Philadelphia, PA, p 1174-1178

Submitted: February 28, 2006; Accepted: September 6, 2006 Proofs received from author(s): November 6, 2006 